\title{
Journalism in the Era of New Media
}

\author{
Ján Višňovský and Jana Radošinská \\ Department of Mass Media Communication, Faculty of Mass Media Communication, University of SS. Cyril and Methodius in \\ Trnava, 91701 Trnava, Slovak Republic
}

\begin{abstract}
The paper deals with the impact of new media (the Internet and new communication devices) on the traditional journalism. In recent years we have witnessed the "battle" between print newspapers and online newspapers published on the Internet. Although publishers and editors have discovered the potential of online newspapers (e.g. economic factors, simple and cheap distribution), in many cases they have become "siblings" of the press. However, there are still many examples suggesting that the online news sites are a standalone competitor to the press. To answer the question of what is the future of print newspapers and whether they have a future in their traditional form, it is necessary to take into account many factors. The authors work with the assumption that newspapers fight to attract the attention of their readers with both content and design. There is a continuous decline in readers' interest in hard news as they often prefer soft news and entertainment. The arrangement of text in online editions of newspapers is different from the press since the online newspapers have a different structure specifically designed for mobile devices such as smart phones and tablets to enable quick and easy manipulation of the online content.
\end{abstract}

Index Terms - journalism, the press, the Internet, new media.

\section{Introduction}

As well as other segments of the media industry, traditional print journalism fights for the interest and attention of the readers within the environment of globalized media communication. According to normative media theories, journalism is supposed to offer objective news and pluralistic opinions related to current social events. On the other hand, the economic imperatives of media industry and efforts to attract and maintain the attention of the readers are the main determinants of contemporary nature of journalism and its products [1].

News and opinions published in newspapers are defined mostly by their importance for the readers and less and less by the attributes of news values such as significance, actuality or impact on the whole society. Other important factors that influence the current trends in making print news include concentration and commercialization of print newspapers and omitting the information function of news in favor of profit. In other words, contemporary print journalism has become a specific kind of entertainment that is able to distract, stimulate, shock, and surprise the reader through attractive expressions and suggestive images. This trend is not evident only in the mass press that naturally works with such principles, but also in the segment of elite newspapers where tabloidization and infotainment are considered as deficiencies. As Pravdová observes, the world of imagination, dramatic stories and emotions is relevant particularly in the context of making news and publishing opinions. Infotainment simplifies the discussed issues and situations, transforms their essence and meaning through dramatization or utter change of authentic events and statements [2].

\section{Journalism as a Part of Our Cultural and Economic Reality}

The daily periodicals - not only in Slovakia, of course currently have to deal with many problems that are symptomatic for the present situation. These issues include:

- Decline in readership of the press,

- Reduction in the number of newspapers and magazines in circulation (even though we can observe a slight increase in the circulation of American newspapers),

- Decrease in advertising revenues as advertisers have been forced to reduce investments in marketing and promotional activities due to the economic crisis.

- Increase in competition from other media, especially television and the Internet, as well as within the press market print newspapers are "fighting" for a stable readership base.

- Increase in the information "supply" (e.g. free news on the Internet).

- Ever changing information needs and entertainment preferences of the readers.

The situation print journalism finds itself in is a result of several factors and circumstances. The recipients are able to access increasing amounts of information offerings. The Internet, television and radio spread news much faster than press journalism. Using new information technologies such as smart phones, tablets or "intelligent" TVs has become a part of our common, everyday reality, especially in case of young and middle-aged people. However, it is necessary to place emphasis on discussing the levels of media literacy in relation with all age groups, e.g. Slovak seniors [3] or addressing the issues of the role of digital technologies in education, including pre-primary education [4].

Decreasing circulation of the press media proves that, generally speaking, people read the newspapers less than in the past and spend more time working and playing with the computers. Moreover, there are also alternative ways of disseminating information, e.g. online social networks [5]. Another fact worth mentioning is that needs for information related to reading newspapers have changed significantly. Few recipients pay attention to political or economic life in society; the readers are interested in tabloid journalism instead, preferring entertainment over information values. The producers of print journalism are well aware of this tendency. Newspapers - more precisely their editors and owners understand that in order to stay "on the market," they have to take countermeasures to eliminate the negative perspectives on the newspaper industry and keep their stable base of readers 
and advertising incomes. These activities include economic dimension of publishing newspapers in terms of doing business (transformation of traditional business models, concentration of ownership, and rationalization of editorial practices, etc.), newspaper contents (tabloidization of topics in daily news, prevalence of "information services," i.e. practical information on common everyday matters, e.g. insurance policy, weight reduction, etc.), as well as ever changing preferences of the readers that more frequently look for "easy topics." Solík and Laluhová observe that hypermedia and the images of the world, people and their behavior significantly influence our perception of the world as such [6].

To "fight back," print newspapers have to use the weaknesses of their competitors to their own benefit. The electronic media, radio, television and the Internet have overshadowed the print media thanks to the speed at which they are able to bring information and news to their recipients. However, since the online newspapers often offer reports about less significant or even insignificant events, we may argue that they lack deeper reflection on major events and important society-wide actions. The print media therefore should use of the shortcomings of their traditional competitors (radio, television, the Internet), e.g. the selective attention paid to audio-visual media content or the ephemeral nature of radio broadcasting, to their own advantage. The "strength" of newspapers lies in their easily comprehensible content editing, effective visualization and in the fact that the readers tend to see the newspapers as the most trustworthy and reliable information sources.

\section{New Media as a Virtual Platform of Journalism}

Formal media typology defines the Internet as one of so called "new media", as a multi-media channel that allows millions of its users to communicate in real time. However, the term "new media" is related also to Web sites, Internet applications and many technologies available via online environment as well as via other types of information and communication technologies, e.g. smart phones, tablets, mp3 players. Using modern information and communication technologies seems to be one of the determining aspects of the new media - the new media available "online" use the Internet as their distribution platform.

Generally speaking, traditional print journalism and online journalism have co-existed for more than fifteen years. Technological advancements of Web 2.0 have created an effective environment to adapt journalism - previously limited to traditional types of media such as the press, photography, film, radio and television - to the specific conditions of the Internet. Even though the Internet has outperformed these traditional media in terms of technological progress, the products of online journalism are partly results of their influence.

The benefits of online communication related to its speed, availability and interactivity cannot be doubted. However, opinions on communication processes, social relationships, cultural environments and human values influenced by dominant electronic communication via the Internet are very diverse. According to McLuhan, the influence of electronic media, including the Internet, is truly significant, mostly because of their ability to change the psychosocial conditions of life and human behavior. The author considers the new media to be "extensions of human senses." These "extensions" shape our central neural system and transform all aspects of our social and psychological existence, including the sphere of relationships [7]. Gálik and Modrzejewski claim that surfing the Internet enables the combination of logically irreconcilable content such as scientific texts with entertaining ones - thus creates a pluriverse of information [8].

French sociologist Lohisse pessimistically observes that technological aspects of communication project themselves into our social relationships - human relations become "cellular." We are not able to predict what kinds of changes will electronic media bring and how will they influence our society, social relations, our thoughts and doings: "An individual, alone with a monitor, engages in a dialogue with the world only through commands typed on a keyboard" [9]. This kind of communication constructs cyberspace ("Technopole") that blurs the boundaries of time and space and links between them. Lohisse's concept of cyberspace places emphasis on the "cellular" society and its configuration within the interpersonal relationships, where individuals are linked to each other by electronic or photonic bonds without the physical presence of the communicating entities [10].

However, new information and communication technologies have brought also new ways of spreading information. The "boom" of smart phones and tablets has resulted in specific formal modifications of online newspapers, taking into account mostly the sizes of displays and functions offered by these mobile devices. Equally important fact is that the number of the newest communication tools is increasing constantly. Naturally, the situation in which journalism has been since the end of the $20^{\text {th }}$ century must be understood not only in economic terms, but also from the viewpoint of social and cultural aspects of human life reflected into the structure of desired information. These tendencies also influence the interest of the readers in print newspapers and the nature of functions these recipients expect from them.

\section{Design of the New Media and Design of Journalistic Information}

The need for an adequate reaction of newspaper industry and editors of print media to the new information and communication technologies is linked to spreading of these technologies throughout the society. Using mobile devices has influenced significantly all processes of journalism. Publishing houses, trying to communicate with the readers and offer them a certain level of comfort during reading, have created special versions of newspapers meant to be read via various types of mobile devices. These electronic products of journalism function as special applications based on the Internet platform and they allow their users to organize and also publish journalistic contents and related texts or reactions.

New ways of publishing on the Internet and existence of applications designed to browse and read online newspapers 
aimed at the users of smart phones, tablets and similar devices are linked to two basic issues that must be addressed by the providers of the contents (media producers). The first issue is related to the selection of textual and audio-visual information meant to be published online and their effective organization in communication space, in other words, their appropriate positioning on the display used by the reader (e.g. computer monitor, display of smart phone or tablet). This "information design" is basically a functional editing of information used to create compact journalistic products. The second issue is to create special kinds of applications that will correspond with the technical features and limitations of communication devices used to mediate the journalistic content, particularly focusing on interactivity and comfort of the readers (users). In this case, we take into account mainly technological design of communication devices to make sure they are available to wide spectrum of users, even to the users with various kinds of physiological disabilities and limitations. These matters are increasingly discussed by scholars, whether in terms of theoretical reflection or empirical research [11].

In accordance with the issues stated above, we define the "information design" as a general approach to arrangement of content and presentation of information in order to communicate particular ideas and news clearly and effectively. Originally developed to improve the usefulness of printed books and manuals, it is now just as likely to be found in the processes of production of the online news. The main goal of the information design - effective communication - is therefore achieved through an absolute focus on the user of the information. Given arguments suggest that information design is related mostly to the content of communication that can be defined by questions "who", "what", and "how." "Design of information" is a process of effective presentation of visual, auditory or audio-visual components in an integrated way. This process takes into consideration the clear differences between using graphic elements to arrange the texts and selecting appropriate visual components (e.g. photographs) that complete the textual information [12].

The available options are determined - as in the case of the press - by quality and range of specific communication space. Even while discussing the issues of online newspapers, we are able to observe that serious events important to the whole society are situated in the most visible places, functioning as an electronic version of the front page. Theory of journalism pays special attention to analyzing the electronic content from various points of view. It is reasonable to assume that Web sites, their design components, and the ways that are used to organize the content reflect the cultural particularities of countries of their origin and, even more importantly, cultural situation of the countries their readers live in.

New media and modern communication devices connected to the Internet are, without a doubt, among the key factors that transform the traditional model of journalism related to print media or to radio and television. Media "evolution" and improvement of electronic communication technologies lead to the development of new forms of editing, organizing and presenting journalistic content and information.
These new journalistic practices are characterized by a high degree of standardization that makes them user-friendly and thus widely available and suitable for the mass audiences.

Assistive technologies facilitate access to the information for people with diverse disabilities. In case of computers and the Internet, assistive technologies include: alternative keyboards, alternative mouse systems, braille embossers, speech synthesizers, haptic devices, optical character recognition devices, screen magnifiers and readers, voice output communication devices, and voice recognition systems. For example, smart phone Samsung Galaxy S4 is able to track the movements of our eyes in order to automatically roll the pages up or down, depending on which way our eyes move.

Media "evolution" takes a major part in development and progress of the newspaper industry all over the world. The indicators that evaluate the current situation on the newspaper market in a global perspective, most importantly the circulation of newspapers and profits from advertising, suggest that the catastrophic scenarios predicting "the end of print media" will not happen any time soon since the print newspapers seem to be able to find their way to improve this unflattering situation, even though it is necessary to admit that their four-hundred-year-long dominance in the sphere of media production is definitely over.

\section{Uncertain Future of Traditional Journalism}

Although the situation in European countries and in the USA is getting worse, Asian countries are indicating (so far only small) increase in press circulation. Also, the number of people who read online newspapers in their different forms and variations is increasing constantly, as well as availability and use of Internet connection and new communication technologies on a global scale. However, we have to take into account also the readers of the final products of journalism. Traditional newspapers are more popular among older and middle-aged people while younger readers tend to read news on social networks or displays of their tablets and smart phones. Social and cultural factors, rituals and customs of the readers are very significant parts of the processes of production and perception of media content. Print media - if they want to "survive" and be successful - will have to adapt to these dynamic communication trends.

Focusing on journalism and its place in the globalized societies of the $21^{\text {st }}$ century, McNair notes that the dominant model of journalism in the $20^{\text {th }}$ century which was represented by professional journalists and objective and reliable journalistic information is currently "fragmented." This "fragmentation" is, in many ways, influenced by new media technologies. Despite many pessimistic visions, McNair does not worry about the future of journalism itself: "Journalism will not die out in this environment, because it is still needed on so many social, political and cultural levels. Journalism has a future. It will evolve, as it has evolved already, from the antique styles of the early newspapers to the gloss and sheen of the modern prime time news bulletin ... But how will it change and will the change be for the better, or for the worse?" [13]. 
Taking into account these uncertainties, we also have to mention a significant shift in the sector of so called "citizen journalism" (also known as "public journalism" or "participatory journalism"). Basically all people who are able to connect to the Internet are also able to freely publish and thus spread their opinions, offering a certain critical alternative by not being dependent on dominant mainstream media. However, this form of participation has been discussed with regards to the quality of journalistic contributions written and published by unprofessional citizen-journalists.

\section{Conclusions}

To answer the questions related to the future of print media and traditional forms of journalism, we have to consider a lot of different factors and contexts. It is hard to tell whether the newspapers will be still published on paper or only electronically, but the need for creating and editing the information content will persist definitely. The influence of information technologies on the journalistic work cannot be doubted. Besides being skilled writers, the journalists also have to know how to use computers and specialized editing software that play an important role in the production of journalistic content. Online newspapers are associated with extended demands related to all editorial positions in publishing since the traditional news are combined with audiovisual materials to properly function within online environment. Most newspapers employ editorial staff members who are in charge of placing the journalistic information online. The specifics of editing the electronic issues of newspapers require a radical transformation of traditional models of editorial work.

Newspapers fight for their readers with both content and design. There is a continuous decline in readers' interest in hard news as they increasingly prefer soft news. Consequently, changes adopted by "elite" newspapers to compete with tabloids are quite evident - adjusting their format to resemble the formal aspects of tabloids, but also producing more "simple" content accompanied by engaging visual graphics. The arrangement of texts within online issues is different from the print versions - online newspapers have a distinct structure designed for mobile devices such as smart phones and tablets that enables quick and easy manipulation of the online content. It is very important to analyze and reflect these trends - as Pravdová and Radošinská state, media texts, whether print or electronic, communicate sets of meanings through their internal and external characteristics. Among the most significant ones are the sorts of chosen narratives, anticipated preferences of the media audiences and ways of constructing and sharing the content [14].

Taking into account the economic reality, the press has been strongly affected by the impact of global economic crisis which has led advertisers to limit their spending or move their marketing activities online, causing significant circulation and advertising revenue decline related to the press [15]. In relation to presentation of the newspaper content, we may conclude that there is a substantial shift in emphasis from texts to pictures. Visualization of information, previously associated mostly with television, is now prioritized in the daily press as well. Unquestionably, eye-catching visuals have a lot of advantages, especially in terms of their ability to represent reality; on the other hand, they are traditionally associated with the phenomenon of tabloid media. As mentioned above, in recent years we have been witnessing "a battle" between traditional newspapers and online newspapers published on the Internet. However, in the light of current development trends of media production, the future result of this presumed "rivalry" is uncertain and almost impossible to predict.

\section{References}

[1] J. Radošinská and J. Višňovský, Aktuálne trendy v mediálnej kultúre (Contemporary Trends in Media Culture), Trnava: Faculty of Mass Media Communication UCM, 2013, p. 83.

[2] H. Pravdová, "Fenomén zábavy a úloha stereotypov v produkcii a recepcii mediálnej kultúry" ("Phenomenon of Amusement and Role of Stereotypes in Production and Acceptance of Media Culture"), Communication Today, vol. 2, no. 1, p. 8, April 2011.

[3] D. Petranová, Mediálna gramotnost' seniorov (Media Literacy of Seniors), Trnava: Faculty of Mass Media Communication UCM, 2013.

[4] D. Petranová and L. Burianová, "Potential of Digital Technologies Use in the Formal Pre-primary Education", European Journal of Science and Theology, vol. 10, suppl. 1, pp. 263-276, October 2014.

[5] J. Laluhová et al., Diskurzívne problémy v masmediálnych štúdiách (Discursive Problems in Media Studies), Trnava: Faculty of Mass Media Communication UCM, 2013, pp. 17-18.

[6] M. Solík and J. Laluhová, "Sociálne uznanie v globálnom priestore: Možnosti a limity mediálnej reflexie" ("Social Recognition on a Global Scale: Opportunities and Limits of Media Reflection"), Communication Today, vol. 5, no. 2, p. 29, November 2014.

[7] M. McLuhan, Člověk, média a elektronická kultura (Man, Media, and Electronic Culture), Brno: JOTA, 2000, p. 97.

[8] S. Gálik and A. Modrzejewski, "Effects of the (Electronic) Media on Cognitive Processes", European Journal of Science and Theology, vol. 10, suppl. 1, p. 24, October 2014.

[9] J. Lohisse, Komunikačni systémy (Communication Systems), Praha: Karolinum, 2003, p. 180.

[10] M. Solík, J. Višňovský, and J. Laluhová, "Media as a Tool for Fostering Values in the Contemporary Society", European Journal of Science and Theology, vol. 9, no. 6, pp. 71-77, December 2013.

[11] N. Vrabec and P. Petkáčová, "Reading Preferences of People with Visual Impairment in the Context of Legislative, Technological and Cultural Changes", European Journal of Science and Theology, vol. 10, suppl. 1, pp. 241-252, October 2014.

[12] S. Jones, Ed., Encyclopedia of New Media, London: Sage Publications, 2003, p. 232.

[13] B. McNair, "Journalism in the $21^{\text {st }}$ Century - Evolution, not Extinction", Journalism, vol. 10, no. 3, pp. 347-349, 2009.

[14] H. Pravdová and J. Radošinská, "Media Culture in the Context of Transformation of Contemporary Spiritual Values and Spirituality", European Journal of Science and Theology, vol. 9, no. 6, pp. 168-170, December 2013.

[15] L'. Č́byová, Marketing a marketingová komunikácia $v$ médiách (Marketing and Marketing Communication in Media), Łódź: Księży Młyn Dom Wydawniczy Michał Koliński, 2012. 